\title{
Pembuatan Automatic Sterilizer Chamber Sebagai Upaya Pencegahan Penyebaran Pandemi Covid-19
}

\author{
Doni Abdul Fatah ${ }^{1 *}$ \\ ${ }^{1}$ Jurusan Teknik Informatika Fakultas Teknik Universitas Trunojoyo Madura \\ Jl. Raya Telang No 02 Kamal Bangkalan 69162 Madura Jawa Timur \\ *E-mail : doni.fatah@trunojoyo.ac.id \\ DOI: https://doi.org/10.21107/pangabdhi.v7i1.8654 \\ Naskah diterima 24 September 2020, Revisi 20 Maret 2021, Terbit 29 April 2021
}

\begin{abstract}
The disease caused by the Corona Virus (Covid-19) is a disease that is transmitted through small droplets that are produced when an infected person coughs, sneezes, or exhales. This droplet cannot stay in the air for a long time, so it quickly falls and sticks to the surface of the floor, hands, or others. Besides, it can be transmitted when someone touches the surface of a contaminated object and then touches the eyes, nose, or mouth. A series of government efforts were taken to minimize the spread of this virus, starting with policies to limit activities outside the home, restricting schools, working, and implementing large-scale regional quarantines, all of which were carried out to reduce the spread of Covid-19. Through the community service program carried out by lecturers and students in contributing to solving problems in society by making Automatic Sterilizer Chambers, the existence of this tool is able to help the local community in dealing with its spread, which can be seen from the good response given by the community or local officials. This was evidenced by the enthusiasm of the participants who came to use the tool either at the village hall, school, or in other public places.
\end{abstract}

Key Words : automatic disinfectant booth, covid-19, droplet, contagion, infected, viruses.

\section{PENDAHULUAN}

Tahun 2020 merupakan tahun yang mengkhawatirkan bagi masyarakat dunia, tanpa terkecuali negara Indonesia. Hal itu disebabkan oleh munculnya wabah virus yang dikenal dengan nama Virus Corona. Virus ini pertama kali ditemukan pada akhir Desember tahun 2019 di Kota Wuhan Provinsi Hubei China (Hui et al., 2020). Virus Corona merupakan bagian dari keluarga virus yang menyebabkan penyakit mulai dari flu hingga penyakit yang lebih berat seperti Middle East Respiratory Syndrome (MERS-CoV) dan Severe Acute Respiratory Syndrome (SARS$\mathrm{CoV}$ ). World Health Organization memberi nama virus ini Severe Acute Respiratory Syndrome Coronavirus-2 (SARS-CoV-2) dan nama penyakitnya sebagai Corona Virus Disease 2019 (COVID-19) (World Health Organization, 2019; Shi et al., 2020).

Penyakit yang disebabkan virus corona (Covid-19) merupakan penyakit yang menular. Penularan virus ini melalui droplet (tetesan kecil) yang dihasilkan ketika orang yang terinfeksi mengalami batuk, bersin, maupun menghembuskan nafas. Droplet ini terlalu berat sehingga tidak dapat bertahan di udara dalam waktu yang lama dalam artian dengan cepat dapat jatuh dan menempel dipermukaan lantai, tangan, maupun permukaan lainnya. Penularan melalui menghirup udara menggunakan hidung ketika seseorang dekat dengan orang yang terinfeksi Covid-19, selain itu penularan juga dapat terjadi ketika seseorang menyentuh permukaan benda yang terkontaminasi kemudian menyentuh mata, hidung maupun mulut.

Peningkatan jumlah kasus Covid-19 terjadi dalam waktu singkat dan membutuhkan penanganan segera. Virus corona dapat dengan mudah menyebar dan menginfeksi siapapun tanpa pandang usia. Virus ini dapat menular secara cepat dan mudah melalui kontak dengan penderita. Karena penularan virus yang sangat cepat inilah, World Health Organization menetapkan virus ini sebagai pandemi pada 11 Maret 2020. Status pandemi global ini menandakan penyebaran virus berlangsung sangat cepat hingga hampir tak ada negara di dunia yang dapat memastikan diri terhindar dari virus corona (Widiyani, 2020).

Saat ini lebih dari 188 negara telah terinfeksi virus ini. Di Indonesia sendiri per tanggal $13 \mathrm{Mei}$ 2020 jumlah kasus terkonfirmasi telah mencapai 
15.438 kasus. Angka kematian mencapai 1.028 orang atau $6,7 \%$ dengan angka kesembuhan kesembuhan 3.287 orang. Selain itu tercatat juga jumlah orang dalam pemantauan yang beresiko tinggi tertular virus dengan jumlah yang diketahui sebanyak 256.299 orang (Rifqi, 2020). Jumlah ini belum menjadi jumlah pasti dikarenakan pemeriksaan terhadap orang yang pernah terlibat kontak dengan penderita belum maksimal. Sehingga resiko penularan virus masih sangatlah besar.

Serangkaian tindakan dan upaya pemerintah diambil untuk meminimalisir penyebaran virus telah dilakukan di seluruh daerah. Diantaranya adalah dengan mengeluarkan kebijakan membatasi aktifitas keluar rumah, kegiatan sekolah dirumahkan, bekerja dari rumah, bahkan kegiatan beribadah tidak boleh di tempat umum. Selain itu beberapa daerah juga menerapkan karantina wilayah besar-besaran atau pembatasan sosial berskala besar (PSBB) (Mona, 2020; Yunus \& Rezki, 2020). Semua langkah itu hanya untuk mengurangi dan membatasi penyebaran virus. Disamping itu kegiatan serupa juga dilakukan seperti langkah-langkah untuk membatasi perjalanan lintas kota, deteksi kasus dan pelacakan kontak, karantina, panduan dan informasi kepada publik, pengembangan alat deteksi (Zhu et al., 2020).

Pengabdian masyarakat (abdimas) adalah salah satu kegiatan yang dilakukan dosen dan mahasiswa dalam kontribusinya menyelesaikan persoalah yang ada di masyarakat. Simbiosis mutualisme antara dosen dan mahasiswa serta masyarakat akan banyaknya pengetahuan, pengalaman yang diperoleh dari dan kepada masyarakat. Sehingga kebermanfaatan program dapat dirasakan masyarakat dan stakeholders atau mitra. Melalui Abdimas dosen maupun mahasiswa dapat mengasah sekaligus mempraktikan ilmu pengetahuan serta menerapkan hasil penelitian yang dampaknya dapat dirasakan oleh masyarakat. Dalam masa yang sulit ini, setiap masyarakat memiliki peran serta yang penting untuk bersama melindungi diri dan lainnya agar selamat dari wabah Covid-19.

Sehingga untuk mengatasi permasalahn yang ada, maka diperlukan beberapa langkah massif untuk memutus rantai penyebaran virus. Salah satu caranya adalah dengan melakukan pembuatan automatic sterilizer chamber atau pembuatan bilik disinfektan otomatis melalui program pengabdian masyarakat yang digawangi oleh Lembaga Penelitian dan Pengabdian
Masyarakat Universitas Trunojoyo Madura (LPPM-UTM) dengan adanya alat tersebut diharapkan dapat membantu dalam menanggulangi persoalan penyebaran wabah pandemi Covid-19 pada masyarakat di desa Banjar Barat Kecamatan Gapura Kabupaten Sumenep.

\section{METODE}

Proses pembuatan Automatic Sterilizer Chamber sebagai upaya dalam pencegahan penyebaran pandemi Covid-19 dalam program Abdimas dilakukan dengan beberapa tahapan yaitu :

\section{Tahapan Perencanaan dan Persiapan}

Pada tahapan ini dilakukan survey ke lokasi tempat pelaksanaan Abdimas, dengan tujuan untuk melihat keadaan dan kondisi lingkungan sekitar, baik melalui wawancara dengan pihak terkait, masyarakat, serta mengindentifikasi tempat atau lokasi serta keperluan apa saja yang menjadi kendala dan menentukan kerangka kerja serta langkah-langkah dalam proses pembuatan bilik disinfektan otomatis juga peralatan apa saja yang harus disiapkan dalam proses pembuatan bilik disinfektan otomatis yang sesuai dengan kondisi tempat pelaksanaan Abdimas.

\section{Tahap Pelaksanaan}

Tahapan ini dilakukan dengan menentukan model atau peralatan dan juga proses pembuatan bilik disinfektan otomatis, menentukan peserta atau masyarakat lokasi Abdimas serta tempat yang akan dijadikan penempatan bilik disinfektan otomatis. Sosialisasi kepada masyarakat dengan cara penggunaan dan memberikan kesadaran dan arahan kepada masyarakat akan pentingnya menjaga kesehatan atau pola hidup sehat sehingga dapat mencegah tertularnya virus Corona, yang tentunya dengan mencuci tangan, memakai masker, makan makannan sehat sempurna, menjaga imun tubuh serta memanfaatkan bilik disinfektan otomatis dalam hal pencegahan penyebaran Covid-19.

Pembuatan dan pengembangan teknologi tepat guna baik berupa pembuatan bilik disinfektan otomatis atau pembuatan alat penyemprotan disenfektan sederhana. Konsepnya dengan melibatkan mahasiswa melalui peran serta aktif bersama masyarakat dalam proses pembuatan dan pengembangan teknologi tepat guna serta menjadi bagian dari masyarakat dalam upaya pencegahan Covid-19 baik dengan memberikan edukasi dan pelatihan dengan memperhatikan standar protokol 
kesehatan sesuai anjuran dari pemerintah, dengan melibatkan mahasiswa Universitas Trunojoyo Madura serta pemuda setempat dalam pembuatan bilik disinfektan otomatis atau pembuatan alat penyemprotan disenfektan sederhana kepada kelompok masyarakat yang berada di wilayah terdampak Covid-19 atau di zona merah yang memerlukan dukungan dalam menanggulangi wabah pandemi Covid-19.

\section{Tahap Implementasi}

Pada tahapan ini pengujian serta pemilihan lokasi untuk penempatan bilik disinfektan otomatis yang tepat sesuai dengan kondisi lokasi tempat pelaksanaan Abdimas berada serta melakukan pemantauan atau evaluasi terhadap pengunaan bilik disinfektan otomatis apakah sudah berjalan dengan semestinya atau masih terdapat kendala, ketika masih ada kendala sehingga dapat diperbaiki langsung terhadap kendala tersebut.

Pelibatan mahasiswa dalam kegiatan pengabdian masyarakat menjadi salah satu kunci keberhasilan program abdimas ini karena disini mahasiswa akan menjadi pendamping, serta mediator dalam sosialisasi program abdimas kepada masyarakat setempat dalam proses pembuatan dan pengembangan teknologi tepat guna sesuai dengan kegiatan program kerja yang telah disusun dan direncanakan antara dosen dan mahasiswa melalui kelompok abdimas yang lokasi pengabdiannya berada di daerah tempat tinggal mahasiswa tersebut.

\section{HASIL DAN PEMBAHASAN}

Berdasarkan tahapan pelaksanaan kegiatan yang telah dijelaskan sebelumnya, untuk kelompok sasaran masyarakat yang dituju dalam program abdimas ini adalah kelompok masyarakat yang bertempat di desa desa Banjar Barat Kecamatan Gapura, Kab. Sumenep. Penduduk desa ini berada di wilayah terdampak Covid-19 sehingga memerlukan dukungan dalam menanggulangi wabah pandemi dalam pembuatan dan pengembangan teknologi tepat guna berupa pembuatan bilik disinfektan otomatis. Kegiatan ini dilaksanakan dengan melibatkan mahasiswa Universitas Trunojoyo Madura serta pemuda setempat dengan memberikan edukasi dan pelatihan dengan memperhatikan standar protokol kesehatan sesuai anjuran dari pemerintah. Kecamatan Gapura sendiri terdiri dari 17 desa/kelurahan mulai dari desa Poja, Beraji, Karang Budi, Baban, Batudinding, Banjar Barat,
Banjar Timur, Paloloan, Panagan, Gapura Barat, Gersik Putih, Gapura Tengah, Mandala, Gapura Timur, Andulang, Longos, Grujugan, dengan total luas wilayah $65,88 \mathrm{~km}^{2}$. Sedangkan Desa Banjar Barat dengan wilayah yang luasnya sekitar 3,20 $\mathrm{km}^{2}$. Luas wilayah tersebut didominasi jenis tanah tanah sawah dan tanah kering sebesar 365,59 Ha. Banyaknya penduduk baik jenis kelamin laki-laki dan perempuan sebesar 3.733 jiwa, serta banyaknya penduduk menurut desa dan jenjang pendidikan baik itu tingkat SD, SLTP, SLTA, Diploma/Sarjana sebanyak 1.728 orang (Badan Pusat Statistik, 2019).

Tentunya tidak semua wilayah dapat terjangkau oleh program ini, akan tetapi prioritas pelaksanaan program beriringan dengan wilayah yang menjadi tempat Abdimas mahasiswa Universitas Trunojoyo Madura Tematik Satgas Covid-19 pada semester genap tahun akademik 2019/2020. Dalam pelaksanaan Abdimas tersebut diprogramkan untuk pembuatan dan pengembangan teknologi tepat guna berupa pembuatan bilik disinfektan otomatis (Automatic Sterilizer Chamber) dengan melibatkan mahasiswa Universitas Trunojoyo Madura serta pemuda setempat dengan memberikan edukasi dan pelatihan dengan memperhatikan standar protokol kesehatan sesuai anjuran dari pemerintah.

Pada prinsipnya kegiatan ini di laksanakan secara daring sesuai dengan tema Abdimas tahun ini adalah pencegahan pandemi Covid-19. Bentuk kegiatan yang dilakukan pada pelaksanaan program ini ditekankan pada upaya untuk menciptakan dan mengembangkan teknologi tepat guna dan memberdayakan masyarakat, kelompok masyarakat, aparat pemerintahan desa atau stakeholders lainnya dalam menghadapi pandemi Covid-19. Adapun hasil dari kegiatan pembuatan dan pengembangan teknologi tepat guna berupa pembuatan bilik disinfektan otomatis (Automatic Sterilizer Chamber) yang dilaksanakan adalah :

- Perencanaan awal untuk pembuatan teknologi tepat guna dengan membuat list bahan-bahan yang dibutuhkan beserta taksiran harganya.

- Mencari bahan-bahan yang dibutuhkan dalam pembuatan teknologi tepat guna.

- Mencari kekurangan bahan untuk pembuatan bilik disinfektan otomatis.

- Merakit pondasi/rerangka awal bilik disinfektan otomatis.

- Proses penyusunan lanjutan rerangka bilik disinfektan otomatis (memasang mika plasting sebagai pembatas di setiap sisi. 
- Perancangan komponen sistem elektronik bilik disinfektan otomatis.

- Tahap penggabungan komponen elektronik dengan kerangka bilik.

\section{Pembuatan Bilik Disinfektan Otomatis (Automatic Sterilizer Chamber)}

Komponen yang digunakan untuk pembuatan alat ini diantaranya dijelaskan pada gambargambar dibawah ini :

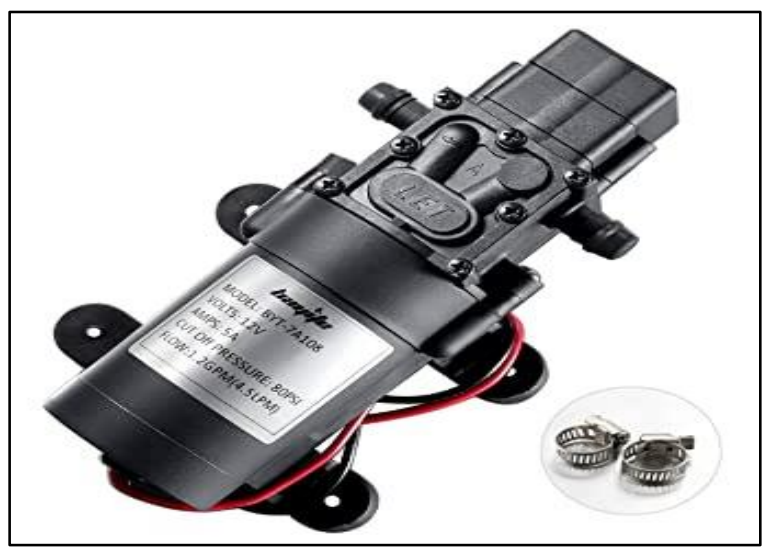

Gambar 1. Water Pump $12 \mathrm{~V}$

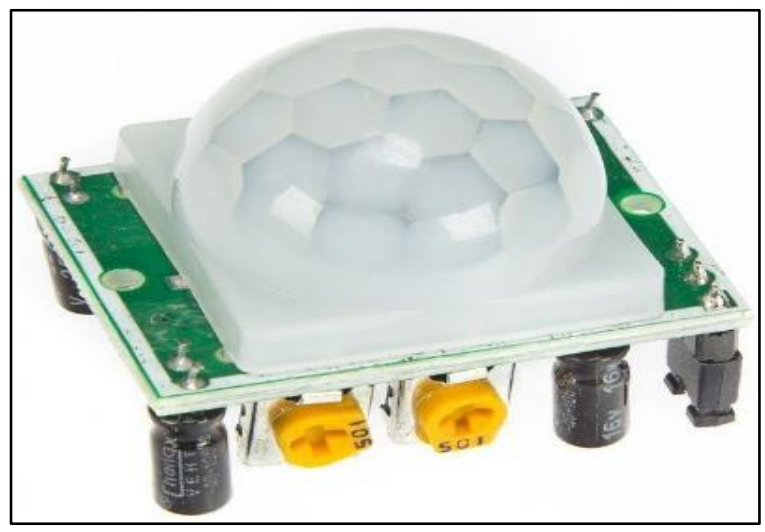

Gambar 2. Sensor PIR Tipe High

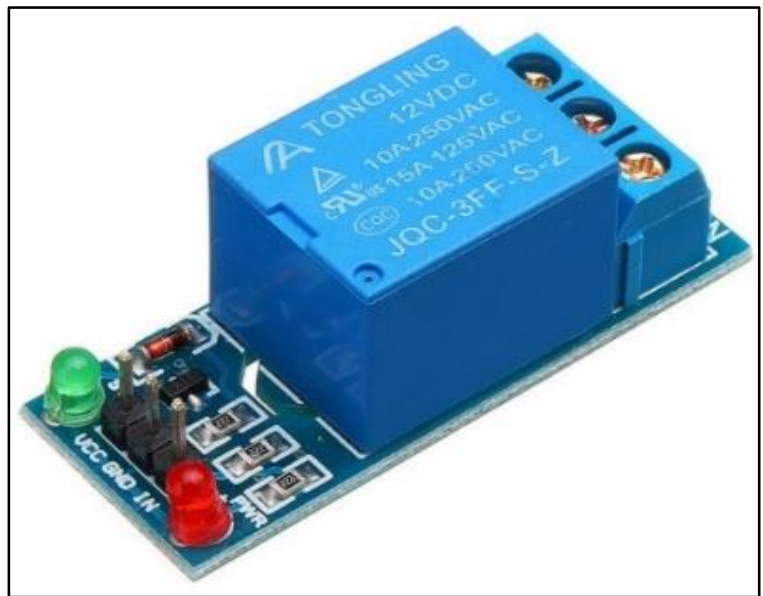

Gambar 3. Relay High Berfungsi sebagai Saklar Pemutus atau Penyambung Arus

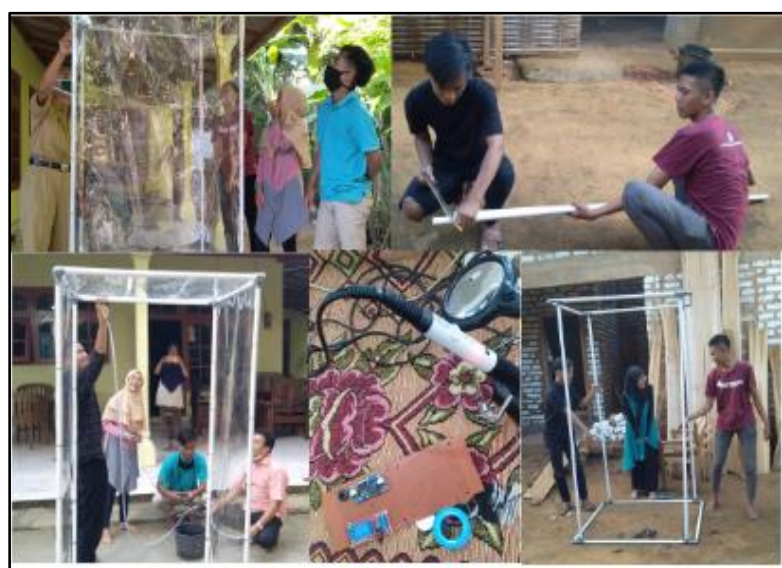

Gambar 4. Proses Pembuatan Alat Bilik Disinfektan Otomatis

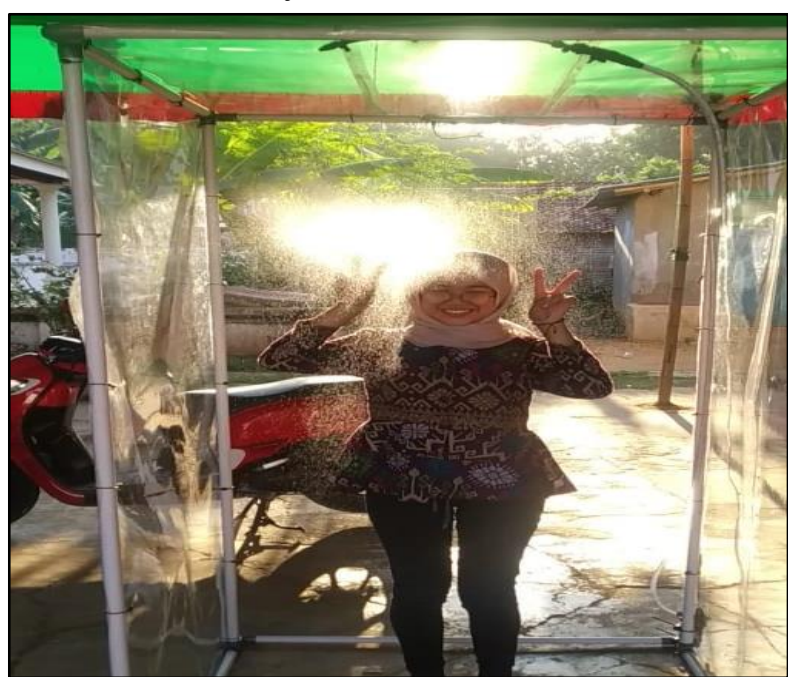

Gambar 5. Pengujian Alat Bilik Disinfektan Otomatis

\section{Manfaat Kegiatan}

Aspek manfaat yang dapat diterima adalah ketersediaan alat untuk mendukung pencegahan Covid-19 di Desa Banjar Barat. Kegiatan ini menghasilkan output yang dapat berguna bagi desa sebagai pelengkap sarana pemutusan penyebaran Covid-19 di Desa Banjar Barat yang juga dapat dirasakan oleh seluruh masyarakat dalam setiap kegiatan yang ada di desa

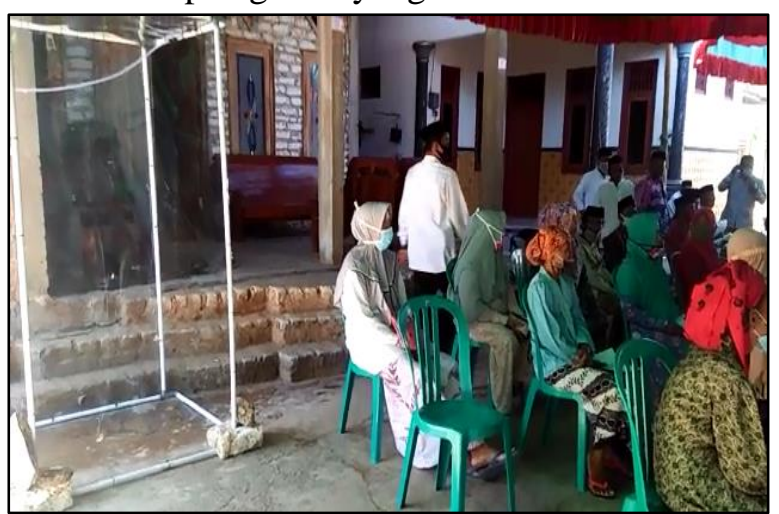

Gambar 6. Penggunaan bilik disinfektan otomatis di Balai Desa Banjar Barat Kec. Gapura 


\section{KESIMPULAN}

Dari kegiatan abdimas yang telah dilakukan dapat di ambil beberapa kesimpulan diantaranya :

1. Kegiatan abdimas telah dilaksanakan di desa Banjar Barat Kec. Gapura, Kabupaten Sumenep

2. Hasil dari kegiatan Abdimas ini adalah berupa bilik disinfektan otomatis (Automatic Sterilizer Chamber) yang mana alat bekerja secara otomoatis ketika ada orang yang lewat kedalam bilik tersebut, kemudian alat tersebut menyemprotkan cairan disinfektan pada orang tersebut.

3. Pada pelaksanaan kegiatan abdimas tersebut juga dilakukan proses sosialisasi dan memberikan edukasi dengan tetap memperhatikan standar protokol kesehatan sesuai anjuran dari pemerintah, dengan melibatkan mahasiswa Universitas Trunojoyo Madura serta pemuda setempat dalam pembuatan bilik disinfektan otomatis atau kelompok masyarakat yang berada di wilayah terdampak Covid-19 yang memerlukan dukungan dalam menanggulangi wabah tersebut.

4. Kegiatan tersebut mendapat respon yang positif dari seluruh peserta baik masyarakat desa ataupu pejabat desa setempat. Hal ini dibuktikan dengan antusiasnya peserta yang datang untuk menggunakan alat tersebut baik di balai desa, sekolah atau digunakan di tempat-tempat umum lainnya sesuai dengan kebutuhan dan kondisinya.

5. Harapan dengan kegiatan abdimas ini adalah mampu memberikan pengetahuan kepada masyarakat tentang pentingnya hidup sehat dan dengan adanya alat bilik disinfektan otomatis (Automatic Sterilizer Chamber) dapat membantu masyarakat setempat dalam menanggulangi persoalan penyebaran wabah pandemi Covid-19.

\section{UCAPAN TERIMA KASIH}

Penulis menyampaikan terima kasih atas dukungan LPPM Universitas Trunojoyo Madura yang telah memfasilitasi jalannya program, juga kepada pihak yang terkait baik dari Desa Banjar Barat Kec. Gapura, Kab. Sumenep serta civitas akademika UTM yang telah berperan aktif dalam menyukseskan program abdimas ini.

\section{DAFTAR PUSTAKA}

Badan Pusat Statistik. (2019). Sumenep Dalam Angka 2019. Badan Pusat Statistik (BPS).
Hui, D. S., I Azhar, E., Madani, T. A., Ntoumi, F., Kock, R., Dar, O., Ippolito, G., Mchugh, T. D., Memish, Z. A., Drosten, C., Zumla, A., \& Petersen, E. (2020). The continuing 2019$\mathrm{nCoV}$ epidemic threat of novel coronaviruses to global health - The latest 2019 novel coronavirus outbreak in Wuhan, China. International Journal of Infectious Diseases. $\begin{array}{lllll}\text { Vol } & 91 & \text { (3). 264-266 pp. }\end{array}$ https://doi.org/10.1016/j.ijid.2020.01.009

Mona, N. (2020). Konsep Isolasi Dalam Jaringan Sosial Untuk Meminimalisasi Efek Contagious (Kasus Penyebaran Virus Corona Di Indonesia). Jurnal Sosial Humaniora Terapan. Vol 2 (2), 117-125 pp.

Setiawan Rifqi, A. (2020). Lembar Kegiatan Literasi Saintik untuk Pembelajaran Jarak Jauh Topik Penyakit Coronavirus 2019 (COVID19). Jurnal Ilmu Pendidikan. Vol 2 (1). 28-37 pp.

https://doi.org/https://doi.org/10.31004/edukat if.v2i1.80

Shi, Q., Dorling, D., Cao, G., \& Liu, T. (2020). Changes in population movement make COVID-19 spread differently from SARS. Social Science \& Medicine. Vol 255. https://doi.org/10.1016/j.socscimed.2020.113 036

Widiyani, R. (2020). Latar Belakang Virus Corona, Perkembangan hingga Isu Terkini. DetikNews. https://news.detik.com/berita/d4943950/latar-belakang-virus-coronaperkembangan-hingga-isu-terkini

World, \& Organization, H. (2019). Coronavirus. World Health Organization. https://www.who.int/healthtopics/coronavirus

Yunus, N. R., \& Rezki, A. (2020). Kebijakan Pemberlakuan Lock Down Sebagai Antisipasi Penyebaran Corona Virus Covid-19. SALAM: Jurnal Sosial Dan Budaya Syar'i. Vol 7 (3). https://doi.org/10.15408/sjsbs.v7i3.15083

Zhu, H., Wei, L., \& Niu, P. (2020). The novel coronavirus outbreak in Wuhan, China. Global Health Research and Policy. Vol 5 (6). https://doi.org/10.1186/s41256-020-00135-6 